\title{
Subject Pronoun Variation in the Northern Italian Geolinguistic Continuum*
}

Introduction

The striking similarity between the Northern Italian and French pronominal systems has been noted by many linguists (cf. Grassi 114, to give but one example). However, not enough is known about how these dialects differ from one another in their subject pronoun systems. The hypothesis to be explored in this study is that the dialects which are geographically situated roughly between French and Italian form a morphosyntactic continuum which parallels the well-documented Northern Italian phonological continuum.

As Chambers and Trudgill (1980:125) point out, the isogloss, despite its traditional prominence in geolinguistic description and in linguistic atlases, does not always in fact do justice to linguistic reality. While a valuable representational tool, isoglosses incorrectly imply an abrupt change from one feature (or set of features) to another. But linguistic reality is in fact far more complex than this convenient visual aid would suggest: language systems tend to blend into one another gradually, at times almost imperceptibly. To date, relatively little attention has been paid to such "transition zones" in the geolinguistic literature (cf. Chambers and Trudgill, 142), and what research there is tends to concentrate on phonetics and phonology rather than morphosyntax, despite the fact that the latter has many highly variable features when examined in the context of nonstandard varieties.

The present study is an attempt to examine one such variable morpho-syntactic feature, the presence of subject pronouns, in the context of the welldocumented dialect continuum of Northern Italy. Various dialectological documentary sources are used to gain a preliminary idea of the scope and the nature of the problem, and to examine some of the issues that arise from it. This methodology allows us (however tentatively) to shed some light on some interesting theoretical questions, such as the dynamics of variation and diachronic change in pronoun systems, the role of lexical diffusion in such processes, and (on a more abstract level) the status of "parameters" in formal linguistic theory. One such parameter is the so-called "null-subject parameter" (cf. Chomsky 55ff, Roberge and Vinet 22). 
The present study does not propose to deal with subject pronouns in such a highly theoretical light, but it retains from this theoretical debate the rather simplistic notion that a subject which is not overtly present can be "recovered" (or identified) by means of verbal suffixes, a subject pronoun, or both. An example of the former is the Standard Italian verbal system, where subject pronouns are optional (parlo or io parlo) and, being stressed, are used for emphatic purposes; in the Standard French verb system, on the other hand, the unstressed subject pronoun (je parle, tu parles etc.) is obligatorily present and identifies the subject; an additional pronoun ( $\underline{m o i}$, je parle) is used for stylistic or pragmatic emphasis.

The French system is in fact a partly mixed one: both the verbal suffix and the subject pronoun distinguish je parle from nous parlons. It nonetheless represents one distinct type, in that a subject pronoun is obligatory before all finite forms of the verb if there is no lexical subject (assuming that imperatives are deemed to be non-finite), whereas in Standard Italian they are optional with finite verbal forms:

..l'italiano (contrariamente al francese) dispone di desineze distinte per le singole forme verbali, il pronome personale risulta superfluo all'espressione delle persone. (Rohlfs 145)

The intent of this study is to move away from relatively "pure" cases such as Standard French and Standard Italian, and to examine more "mixed" or transitional cases in which subject pronouns, either stressed or clitic, may be obligatory in all or part of the verbal paradigm. As Rohlfs (146) notes, in contrast to the situation in literary Italian and Southern dialects:

Ben diversamente stanno le cose nel Settentrione.... Nei dialetti moderni invece il pronome è divenuto quasi ovunque complemento obbligatorio della forma verbale. Ora compare soltanto nelle forme toniche (ven. mi son, lu ga), ora solo nella forma ridotta (mil. a sont 'io sono' ), ora il verbo è preceduto da entrambe le forme, tonica e atona (ven. ti ti gavarà 'tu avrai').

It should however be noted that Standard French does not represent the most developed case of a subject system, since many of the Northern Italian dialects require pronouns in contexts where they need not, or indeed may not, appear in French. For example, while both Standard French and many dialects allow unstressed subject pronouns to be preceded by an emphatic pronoun (French moi, je viens, Piedmontese mi $i$ kantu), Standard French does not permit a lexical subject followed by a subject pronoun, as do many Northern Italian dialects: Turinese Mario a parla, Trentino el Mario el parla, etc. (Bracco, Brandi and Cordin 195). In some Northern Italian dialects the subject pronoun in fact appears twice, once as a proclitic and once as an enclitic. This leads to a 
situation which can be described as pronoun tripling (e.g. Milanese ti te parlet, Nicoli 138, where the final $-t$ has acquired the value of a verbal ending), where the enclitic has become an integral part of the verbal morphology (and not, as in varieties such as Friulian, only in interrogative and other inverted constructions), the proclitic subject is obligatory, and the stressed subject pronoun is added for emphasis. While subject doubling is characteristic of some varieties of French, such subject pronoun "tripling" does not seem to be found elsewhere in the Romance languages.

A brief note on terminology is in order at this point. A fairly wide variety of terms have been used in the descriptive dialectological literature to designate the forms which are of interest in this study, most often called simply pronomi atoni or deboli. One finds them called, for example, particelle (Griva, Mainoldi), pronomi secondari (Mora), duplicazione pronominale (Rossini), accompagnaverbi (Tonetti), pronomi personali pleonastici (Marchetti), and, perhaps most aptly, pronomi personali verbali (Brero and Bertodatti). While the terms "clitic" is of course itself ambiguous, since it can apply to object pronouns (direct and indirect) as well as to non-pronominal elements (such as negative particles and some adverbs), unless specified otherwise the term refers to subject clitic pronouns in the context of the present study.

\section{Varieties Studied}

In reality, the "pure" cases alluded to above (complete absence vs. presence of subject pronouns) do not correspond exactly to any geographical area: neither Standard French nor (especially) Standard Italian can be described as the dialect of a particular region, since neither is spoken naturally by any regional population. The varieties studied do, however, fall roughly between where these two idealized "poles" might be geographically deemed to be: the area in question is situated between the Italo-French border in the north-west, the Istrian peninsula in the east and Florence in the south. Note that this describes the area north of the famous La Spezia-Rimini line. In theory, any lingusitic continuum can be considered almostly infinitely "smooth" when examined on a sufficiently fine scale. Such detail is not, however, always practical, and the first part of this study concentrates on some thirteen (sub-) varieties spanning the principal Northern Italian dialect groupings as outlined by Savi (10-11). More specifically, evidence is gathered on Piedmontese (Brero and Bertodatti, Aly-Belfaddel, Griva 1980), Lombard (Massariello Merzagora), Mendrisiotto (Lurà), ${ }^{2}$ Milanese (Nicoli), Cremonese (Rossini), Valseviano (Tonetti), Bergamasco (Mora), Veneto (Zamboni), Rovigno (Deanovic), Friulan (Frau), Bolognese (Mainoldi), Romagnolo (Pelliciardi) and Florentine (Renzi). These varieties are shown in Map I. 


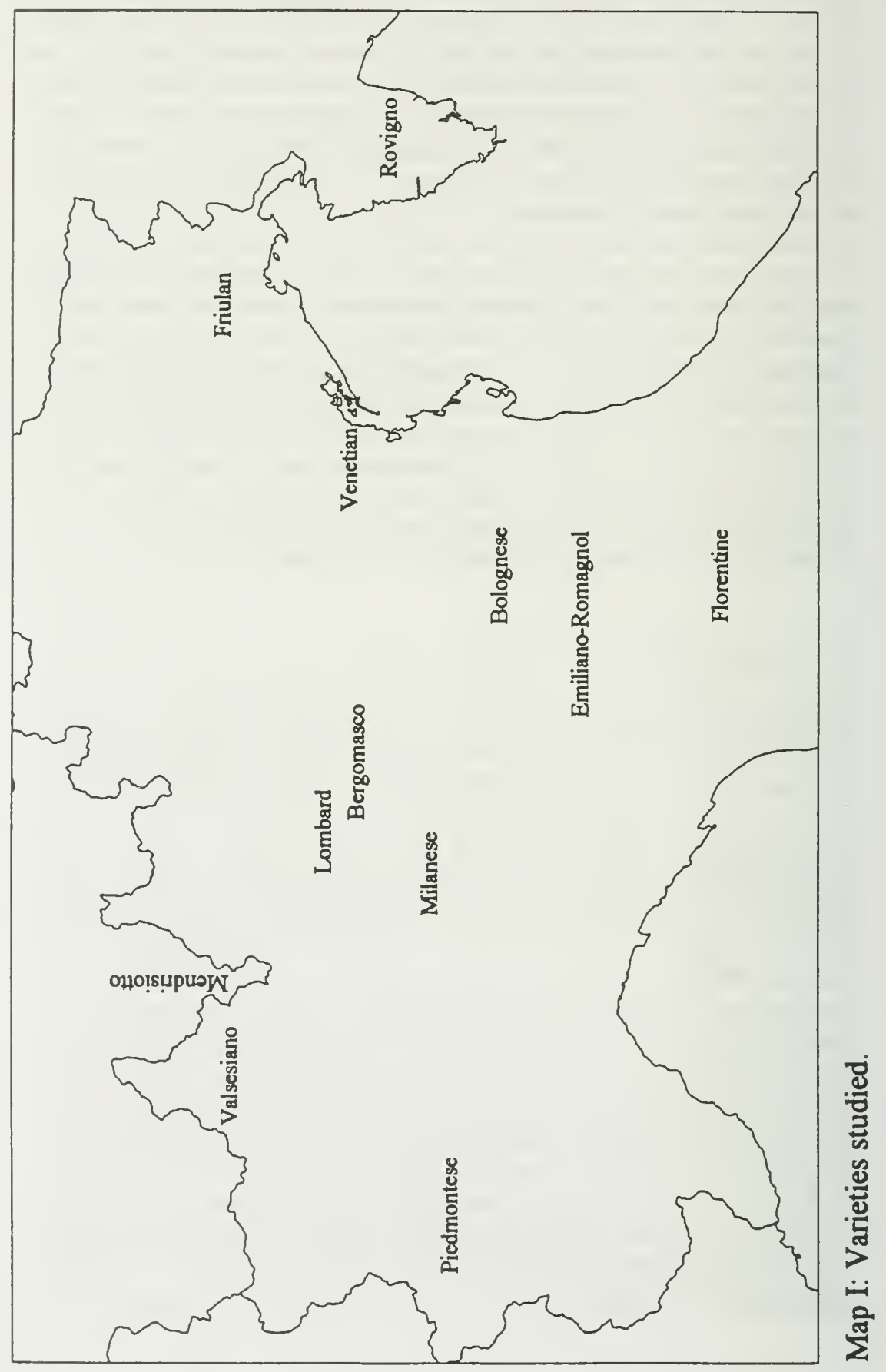


While some of these descriptive monographs on a dialect or group of dialects are very useful, they are on the whole highly variable in approach and consistency, and, at best leave many questions unanswered. There is also a lamentable lack of adequate descriptions for certain varieties (Ligurian, Trentino). For these reasons, the second part of this study focuses on a certain number of maps from Jaberg and Jud's Sprach-und Sachatlas Italiens und der Südschweiz (hereafter $A I S$ ), especially from volume 8), covering phrases or expressions with finite verbs, which were used as primary data to supplement the dialect descriptions cited above.

\section{Methodology}

Many of the more specific aspects to be studied in each dialect were inspired in part by the approach presented succinctly in Renzi and Vanelli, who formulate some interesting generalizations about the pronoun systems in some 30 dialects, but do not address the question of where these systems are situated geographically. Similar questions have of course been raised by other linguists, including Rohlfs (1966:46ff) and Bracco, Brandi and Cordin.

Since in all the varieties studied there are at least some subject pronouns, the first and most important question to be examined in each case is how many subject pronouns there are, and in which grammatical person $s^{3}$ of the verb they appear. It must be kept in mind. however, that the simple number of pronouns is not necessarily the most significant factor: it is also necessary to determine whether or not there is any neutralization between the pronoun forms for the various persons, that is, if any of the subject pronouns have the same form for different grammatical persons. ${ }^{4}$ In these cases, the verbal endings may serve to disambiguate any neutralizations that may exist among the subject pronouns, just as conversely, the subject pronouns may help distinguish between identical verbal suffixes. It must be emphasized that, in any case, the actual phonetic form of the pronouns is of little consequence for this study: what is important is the pronominal paradigm, i.e. the number of grammatical persons which are distinguished.

Where possible, we will also determine the various linguistic contexts which may affect the occurence (or non-occurence) of subject pronouns. When they co-occur with nominal subjects, pronouns may be either preposed or postposed (i.e. $\mathrm{NP}+\mathrm{cl}+\mathrm{V}$ or $\mathrm{NP}+\mathrm{V}+\mathrm{cl}$ ). Impersonal, meteorological, and existential verbs (as well as avere) may or may not take pronominal subjects, in contradistinction to other verbs. Finally, subject pronouns may or may not appear after quantifiers like chi and nessuno, and in negative, interrogative and inverted constructions; in this last case, the form of the enclitic will often differ from the form of the proclitic. 


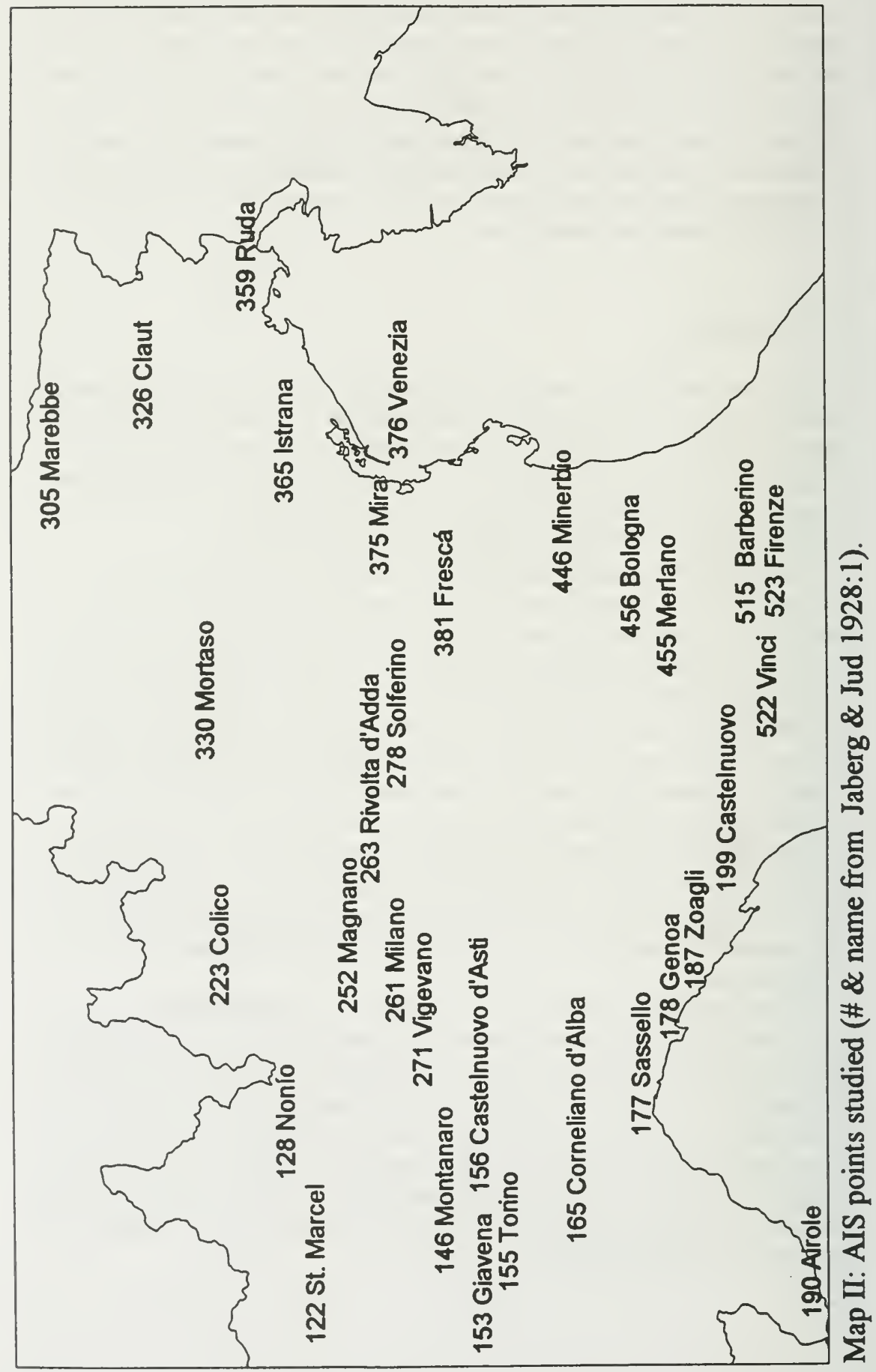


While the choice of descriptive monographs is largely imposed by the availability of adequate studies, the same is not true for the choice of points from the AIS. Thus, for the second part of this study, a representative sampling of points was selected from among the dialect regions as outlined above (cf. Savi 80), but taking into account the dynamic between urban and rural points, as well as the probable role of the former as centres of linguistic diffusion into surrounding rural areas (Chambers and Trudgill 189ff). Thus six major cities were chosen (Turin, Milan, Venice, Bologna, Genoa, Florence), along with two or three points immediately around each of them and a number of points spread throughout each dialect region. In all, data were collected from a total of thirtytwo points (shown in Map II) on thirty-eight AIS maps comprising a representative sample of finite verb forms in different grammatical persons and in different linguistic contexts.

As mentioned above, this study does not take into account the various phonetic forms that subject pronouns may take in each variety. Thus the fact that the second person occurs as [ta], [at], [t $\boldsymbol{\varepsilon}],[\mathrm{te}],[\mathrm{ti}],[\mathrm{t}-],[-\mathrm{t}],[\mathrm{it}],[\mathrm{tu}],[\mathrm{to}]$, [ad], [et], [ty] (and perhaps as other forms as well) is of less concern than the simple fact that the varieties in question have a second person pronoun. To put it differently, one expects a fair amount of (inter- and intra- dialectal) variation, both phonological and allomorphic) in any morphological system. This is all the more true given that clitics, being unstressed, are subject to somewhat irregular phonetic developments. ${ }^{5}$

Indeed, the degree of morphological variation is so great that it becomes difficult at times to determine whether a given form is in fact a subject pronoun (as discussed below). For the sake of consistency, any unstressed form appearing before (or in some cases after) a finite verb and not corresponding to any other grammatical function was considered a subject pronoun. This may consist of as little as a consonant alone (e.g [t-] or [1]) or as much as two unstressed syllables ([ara]). Note that any map with an Italian gloss which contains a subject pronoun is assumed to involve contrastive or stylistic stress, and is thus excluded (e.g. AIS maps \# 1627 Gli parlerei $\underline{\text { ion}}$ \#1629 se $\underline{\text { tu }}$ lo trovassi, etc.). The maps chosen are, in order by grammatical person:

1. 887 , ho messo

1519 , vorrei di questa qui

1597 , non lo trovo

1619 , sono tulto stordito

1645, sento un rumore

1658, non capisco

1677, ho i piedi bagnati
2. 1016, mangeresti?

1539, hai cucito bene

1586 , perchè hai scello...?

4. 1604, che corressimo sempre

1613, lavoremmo di più

1635, abbiamo cercato

1646 , siamo arriviati 
3. 363 , che tempo fa?

366, piove

367 , è piovuto

377 , nevica

1532, cuciva

1534, cantava sempre

1549 , è sudicia

1550, c'è una macchia

1594 , non vuol rimanere

1602 , il nostro padrone è cattivo

1603 , vorrebbe

1605 , lui non corre mai

1630 , non sarebbe contento

1636, è la terza volta

1678, questa donna non mi piace
5. 1590 , che me dovete

1595 , credete?

1598 , siete venuta

1599, avete guadagnato
6. 1555 , sono stracciati

1558 , sono logorati

1661 , faranno cio che voranno 1667, l' hanno cacciato

\section{Results and Interpretation}

\subsection{General Survey}

Table I shows the data gathered from the first part of the study, with descriptions covering some thirteen dialects. While some general features can be gleaned from such a survey, the combination of frustrating gaps in data and too much idiosyncratic information makes meaningful comparison between dialects next to impossible.

Table I

\begin{tabular}{|l|c|c|l|}
\hline Variety & $\begin{array}{l}\text { Number } \\
\text { of Pronouns }\end{array}$ & $\begin{array}{l}\text { Distinct } \\
\text { Persons }\end{array}$ & Specific Usage Facts \\
\hline Florentine & 2 & 2 & may follow lexical subject \\
Emiliano-Romagnol & 6 & 4 & [s] omitted with avere in 1, 4, 5 \\
Bolognese & 6 & 4 & endings distinguish persons 1,4,5 \\
Veneto & 3 & 3 & 3 endings =6; s distinguish \\
Friulian & 6 & 4 & [s] omitted in certain cases \\
Rovigno & 6 & 3 or 4 & 1=4=5, sometimes =6 \\
Lombard & 4 & 4 & 2, 5 enclitic in questions \\
Bergomasco & 4 & 4 & also 5 with avere \\
Cremonese & 3 & 3 & omitted after indefinites \\
Milanese & 3 & 2 & 1, 4, 5, 6 optional \\
Piedmontese & 6 & 3 & $1=4,5 ; 3=6$, (ending all distinct) \\
Valsesiano & 6 & 3 & [s] distinguishes 2,5 \\
Mendrisiotto & 6 & 3 or 4 & absent in impersonals; 6=1,4,5 \\
\hline
\end{tabular}


Although rather sparse, these data already suggest some of the general trends which require fleshing out by further study. It should be clear that the system which distinguished the fewest persons occurs in Florentine, and that the number increases as we move north-west and north-east. The fact that two varieties are shown as distinguishing " 3 or 4 " persons is indicative of the sort of inherent variability which will be even more marked in the second part of this study.

\subsection{AIS Maps}

In a sense, one could have hoped that all the relevant information on verb forms, including subject pronouns, would be compiled in the "Tavole della conjugazione" toward the end of the AIS (8:1683ff). But in fact these tables are mainly concerned with verbal morphology stricto sensu (i.e. verb endings), and the subject pronouns are only given once, with the "sample verb" in -are (8:1683). Unfortunately, the verb chosen for the northern part of the Atlas is lavarsi, which complicates matters somewhat given that the emphatic subject pronoun and the reflexive pronoun are both present, and the subject (where it exists) may or may not be present. The more serious problem is, of course, that reducing all responses to one sample verb inevitably masks the inherent variability of the actual responses from each subject to each question.

The reality of geolinguistic questionnaires, however well-designed, is that they sometimes elicit responses that are not what was expected or intended. Thus in AIS maps \#1604 and \#1613, instead of the intended 4th person forms, we find normal spoken Tuscan equivalents (si coresse, si lavorebbe) at the three southernmost points. Furthermore, the one form which appears at each point on a linguistic atlas map does not, as a rule, inform us as to whether it is the only possible structure or one possibility among many, and in the latter case, exactly what the range of acceptable possibilities might be. Thus there are a number of pitfalls (beyond the simple recognition of subject forms) in tabulating the data from the AIS maps. There may be no data at a given point on a given map, or the subject may have responded using a totally different construction which does not include a subject. These cases were recorded as "no data" and were excluded from the calculation of results. Cases in which no subject pronoun appeared, or in which a stressed subject pronoun appeared, were recorded as "no", while all cases with an unstressed subject pronoun (regardless of its form or position) were counted as "pronoun". Since the goal was to discover where $s$ are possible, multiple responses (as in the cases of some major cities) were counted as "pronoun" if at least one of the responses contained a subject pronoun.

The inherent variability of responses has the further result of restricting (or at least disguising) the "constant" usage of subject pronouns, even in varieties 
which are recognized as having complete subject paradigms. Thus if we tabulate the responses for each map by grammatical person, we find that no point has $100 \%$ usage in all persons; in fact, the highest number of subject pronouns attained by this method of calculation is only a paradigm of three persons with completely consistent usage (second, third and fifth in the case of Giaveno, and second, third and sixth in the case of Calico).

This distribution, which is shown in Map III, combined with the fact that most of the cases with 100\% usage fall in the second person, confirms Renzi and Vanelli's (143-44) first two generalizations:

1. Se una varietà fa un uso costane di almeno un pronome soggetto, questo è quello di 2. persona.

2. Se una varietà fa un uso costante di almeno due pronomi soggetto, questi sono quelli di 2. e 3. persona.

However, these same data do not support Renzi and Vanelli's next two generalizations (144):

3. Se una varietà fa un uso costante di almeno tre pronomi soggetti, questi sono quelli di 2., 3.,e 6. persona.

4. Se nella 2.,3. e 6. persona il pronome è presente, non può mai essere opzionale.

These two generalizations are further undermined if we tabulate those cases where half or more of the forms in question have a subject pronoun. This criterion of "near uniformity" better reflects the descriptive literature on these varieties, and gives us the geolinguistic pattern shown in Map IV.

The pattern which emerges from these data is one in which there are still two points where usage is most generalized: Giaveno and Bologna, with a majority of $s$ in all six persons. These points are flanked by areas of fairly consistent subject pronoun usage (in 3 to 5 persons), corresponding grosso modo to the Emiliano-Romagnol and Piedmontese dialect zones. It should also be noted that the two areas where there is little or no subject pronoun usage (i.e. less than $50 \%$ in all 6 persons) are adjacent to these areas of high usage. While these abrupt transitions apparently contradict the general pattern of gradual transitions from one pronominal system to another, it must be remembered that geographical proximity does not necessarily reflect patterns of human activity and mobility. Thus Barberino and Vinci (the latter with only one occurence of a subject ) represent the Tuscan norm on which the Standard Italian system of optional strong subject pronouns is modeled. The absence of subject pronouns at Genoa and Zoagli is harder to explain, but it is evident that these coastal Ligurian communities have many more maritime links than nearby Sassello, which is more similar to its Piedmontese neighbours to the north. 


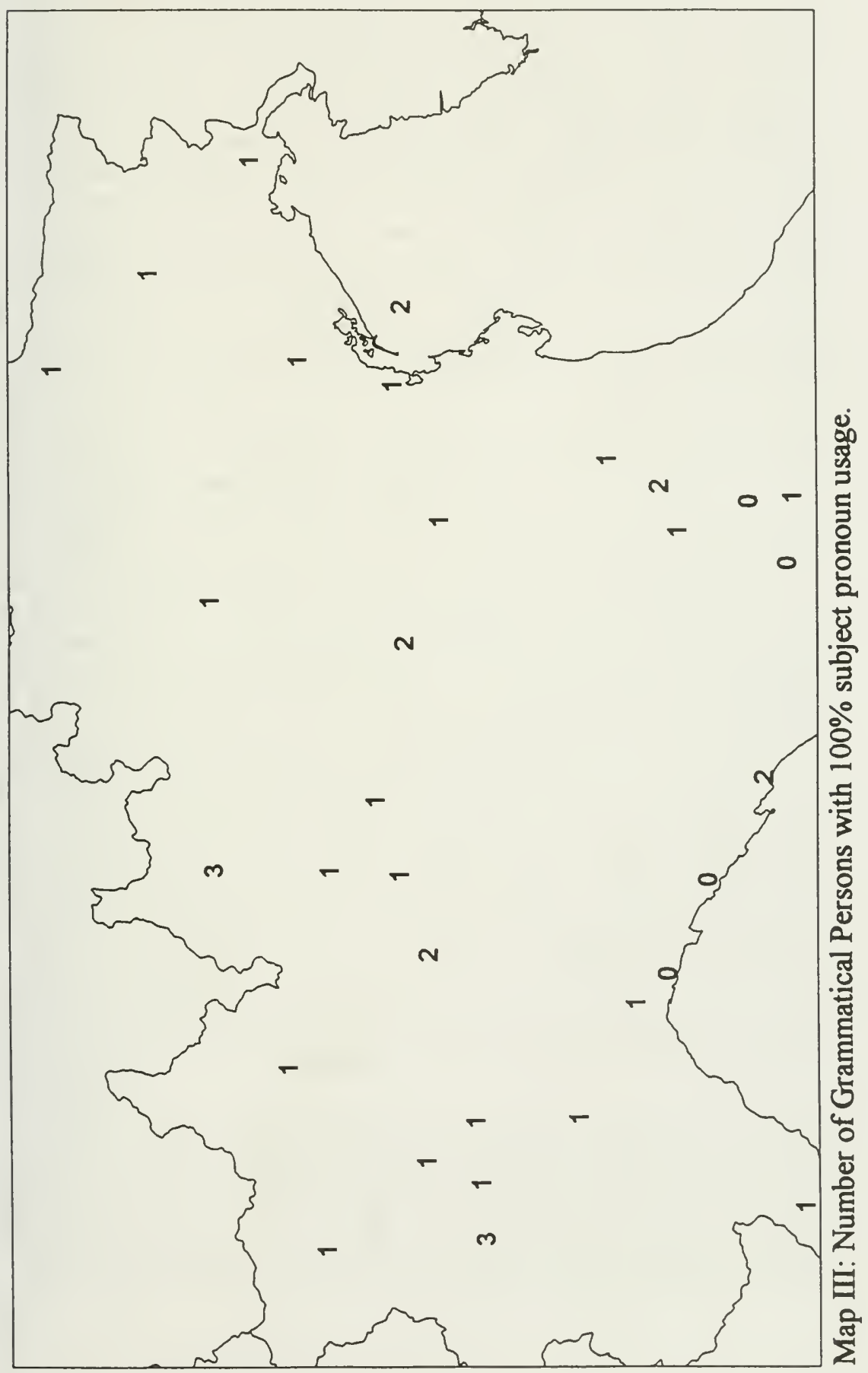




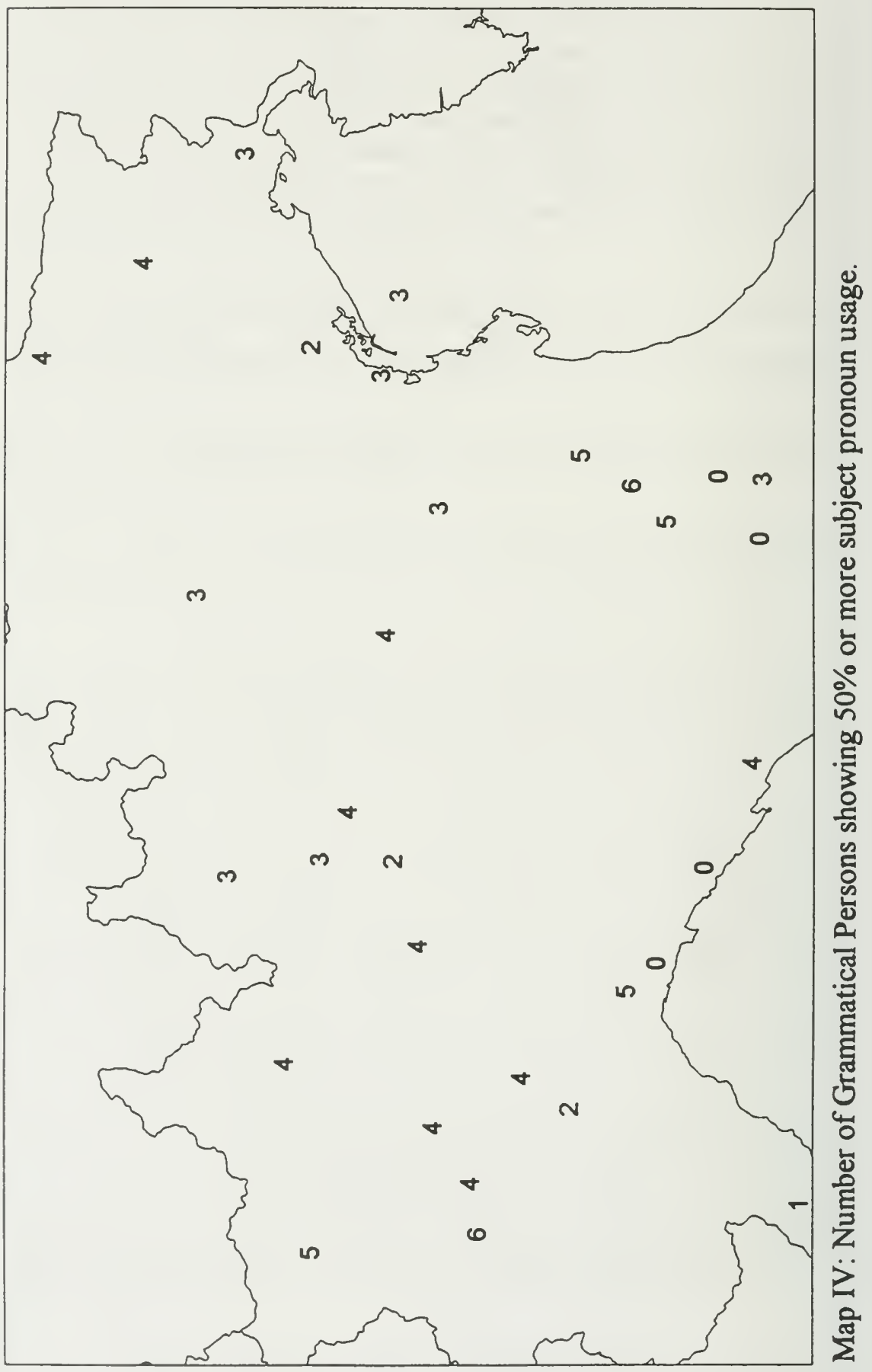


4. Conclusions: Problems and Hypotheses for Further Research

It must of course be recognized that the present study is necessarily very preliminary in nature; it is more of an initial survey based only on those materials which were most readily accessible. In addition to linguistic descriptions, where they exist, consideration ought also to be given to literary texts, especially those of a popular or folk (as opposed to learned) register. As discussed below, this would be particularly useful in order to gain an idea of the historical evolution of this type of pronoun system. Finally, the use of more AIS points would have provided a denser pattern of data, thus giving a more sophisticated picture of just how these subject systems vary from one area to the next. We still need to discover more about how these different systems work. Not enough is known about the various contexts where $s$ are permitted, optional, or required in the various dialects. The relevant contexts simply do not always appear in the AIS maps, nor are they covered by the descriptive literature. Consequently there is not enough data to determine definitively the status of subject pronouns after quantifiers like chi and nessuno, or with negation.

With these caveats in mind, it nonetheless seems that some interesting problems have been raised and some hypotheses can be advanced and/or confirmed. Major urban centres do seem to have some effect on surrounding areas, but the direction of their effect is somewhat ambiguous: Venice, Florence and Bologna have more subject pronouns than their immediate neighbours, while Milan and Turin have fewer. Furthermore, in Venice we find the order pronoun \pm neg., while in nearby Mira the order is neg. + pronoun; this comparison is further complicated by the fact that negation can be expressed either before the verb (of the type: ne) or after (of the type: pas) or both.

The systems studied here range from the typical Tuscan type (represented by Vinci) to a paradigm very reminiscent of the French one (at St. Marcel), with all the gradations in between. The fact that the spatial transition from one type of pronoun system to another is gradual lends support to the lexical diffusion hypothesis (cf. Wang). While this hypothesis usually deals with phonetic change in lexically "full" (or content) words, it seems intuitively plausible that change in grammatical status should also occur on an item-by-item basis throughout the lexicon. And indeed, the tentative results of this study seem to show that, at very least, there is no geographically abrupt shift from one system to another. ${ }^{6}$

This spatial continuum would suggest that the historical shift is also gradual rather than abrupt. The exact nature of the diachronic changes in question cannot, of course, be conclusively ascertained without a detailed study based on a historical corpus of more or less "oral" texts from one variety, something which is beyond the scope of this study. The synchronic geolinguistic data presented do, however, suggest a sort of "implied motion", reminiscent of the 
famous Jakobsonian metaphor of a snapshot of a person walking down a street: immobile in itself, but capturing a moment out of a continuum of motion.

If this view of diachronic change in pronoun systems is correct, then it in turn has implications for the notion of parameters in a generative grammar. Gradual lexical diffusion of a change through a pronominal system is ultimately incompatible with the view of linguistic parameters as binary options which are "set" on the level of an abstract Universal Grammar, and hold throughout a given language variety. Such a view makes it difficult to conceive of a mixed paradigm (with some persons having subject pronouns and some not), and quite impossible to account for the spread of pronoun usage from one grammatical person to another, since the latter would seem to be exactly the sort of situation documented by the data in this study, we are forced to reassess our ideas about linguistic parameters (such as the "null subject parameter") and how they are set. Instead of parameters valid for a whole grammar, what we are faced by are parameters as features of individual lexical items, which are "set" on an atomistic, item-by-item basis (cf. Borer, Wexler and Manzini). Only in this way can we convincingly account for the type of variation this study documents both within and between varieties in the Northern Italian dialect continuum.

\section{University of Western Ontario}

\section{NOTES}

* This is a revised version of a research paper completed in September, 1992, under the direction of Professor G.P. Clivio, for whose guidance and suggestions I am very grateful. Members of the Groupe de recherches en dialectologie comparative also made helpful suggestions and comments regarding earlier versions, as did Anna Moro and Jeff Tennant. This research has been partly funded by SSHRCC.

1 In a footnote, Rohlfs goes on to clarify that, in certain exceptional circumstances, subject pronouns are required in Standard Italian, for example to disambiguate cases where verbal endings are not distinct: voglio che tu venga, voglio che lui venga, vuole che io venga. Freedman examines some other cases where subject pronouns are used in Modem Standard Italian.

2 Whle actually spoken in Switzerland, the Mendrisiotto dialect is included since it forms part of the same linguistic continuum as the other varieties.

3 For the sake of claity, grammatical persons are conventionally numbered 1 through 6 in this study (with persons 4 to 6 corresponding to those also called 1 st, 2 nd and 3 rd person plural).

4 The term "neutralization" is used here in the sense of "syncretism", as defined by Jeffers and Lehiste (186): "Developments whereby grammatical distinctions are eliminated, either through phonetic change or through analogical processes." This is also clearly the sense in which lliescu uses the term syncrétisme: "Dans le paradigme de la flexion verbale friuolane, où le syncrétisme est un phénomène assez répandu, vu que dans un temps donné peuvent être identiques une, deux, ou même trois paires de formes verbales, le pronom atone en nominatif a commencé à assumer la fonction de morphème du verbe."

5 More specifically, the Piedmontese "particelle pronominali" $l$ " and $j$, which do not inflect for person and are only found with the verbs avej and some tenses of the 3P of esse (Brero and Bertodatti 75) are not taken into account here. 
6 A detailed analysis based on more ample data from both Northem ltaly and South-Central France appears in my doctoral thesis, La variation grammaticale en géolinguistique: les pronoms sujet en roman central.

\section{WORKS CITED}

Aly-Belfàdel, Arturo. Grammatica piemontese. Noale: L. Guin, 1933.

Bellosi, Giuseppe, and Giovanni Quondamatteo. Le parlate dell' Emilia e della Romagna. Firenze: Edizioni del Riccio, 1979.

Benincà, Paola, ed. "Introduction." Dialect variation and the theory of grammar. Dordrecht: Foris, 1989. 1-8.

Borer, Hagit. Parametric Syntax. Dordrecht: Foris, 1984.

Brero, Camillo, and Remo Bertodatti. Grammatica della lingua piemontese. Torino: Edizione Piemont/Europa, 1988.

Bracco, Claudio, Luciana Brandi, and Patrizia Cordin. "Sulla posizione soggetto in italiano e in alcuni dialetti dell'Italia centro-settentrionale." Sintassi e morfologia della lingua italiana d'uso: Teorie e applicazioni descrittive. Rome: Bulzoni, 1985. 185-209.

Chambers, Jack, and Peter Trudgill. Dialectology. Cambridge: Cambridge UP, 1980.

Chomsky, Noam. Lectures on Government and Binding. Dordrecht: Foris, 1981.

Coco, Francesco. Introduzione allo studio della dialettologia italiana. Bologna: Pàtron, 1982.

Deanovic, Mirko. Avviamento allo studio del dialetto di Rovigno d'Istria. Zagreb: Graficki zavod Hrvatske, 1954.

Frau, Giovanni. Friuli (= Profilo dei dialetti italiani 6). Pisa: Pacini, 1984.

Freedman, Alan. "«Vuoi tu murare?» The italian subject pronoun." Studi di grammatica italiana 12. Firenze: Accademia della Crusca, 1983. 167-90.

Grassi, Corrado. Elementi di dialettologia italiana. Torino: G. Giappichelli, 1970.

Griva, Guido. Grammatica della lingua piemontese. Torino: Viglongo and C. editori, 1980.

Heap, David. "Subject pronoun variation in Central Romance." $(N)$ Waves and Means: a selection of papers from NWAVE 24. Ed. Miriam Meyerhoff. Philadelphia: University of Pennsylvania Working Papers in Linguistics 3.1(1995): 43-50.

- "La variation grammaticale en géolinguistique: les pronoms sujet en roman central." Ph.D. dissertation, University of Toronto. Distributed by the Toronto Working Papers in Linguistics. 1997.

Iliescu, Maria. Le frioulan à partir des dialectes parlés en Roumanie. The Hague: Mouton, 1972.

Jaberg, Karl, and Jakob Jud. Sprach- und Sachatlas Italiens und der Südschweiz. 8 vols. Zofingen: Ringier, 1928-1940.

Jeffers, Robert J., and Ilse Lehiste. Principles and Methods for Historical Linguistics. Cambridge (MA): MIT Press, 1982.

Lurà, Franco. Il dialetto del Mendrisiotto. Mendrisio-Chiasso: Edizone Unione di Banche Svizzere, 1987.

Mainoldi, Pietro. Manuale dell'odierno dialetto bolognese. Bologna: Società tipografica Mareggiani, 1950.

Marchetti, Giuseppe. Lineamenti di grammatica friulana. Udine: Società Filologica Friulana, 1952.

Massariello Merzagora, Giovanna. Lombardia. Pisa, Pacini, 1988.

Mora, Vittorio. Note di grammatica del dialetto bergamasco. Bergamo: Edizioni Orobiche, 1986.

Nicoli, Franco. Grammatica milanese. Busto Arsizio: Bramante Editrice, 1983.

Pelliciardi, Ferdinando. Grammatica del dialetto romagnolo: la lèngva dla mi tera. Ravenna: Longo Editore, 1977.

Renzi, Lorenzo. "Fiorentino e italiano: storia dei pronomi personali soggetto." Ed. F. Albano Leoni et al. Italia linguistica: idee, storia, strutture. Bologna: 11 Mulino, 1983.223-39.

Renzi, Lorenzo, and Laura Vanelli. "l pronomi soggetto in alcune varietà romanze". Scritti 
linguistici in onore di GB. Pellegrini. Pisa: Pacini, 1982. 121-45.

Roberge, Yves, and Marie-Thérèse Vinet. La variation dialectale en grammaire universelle. Montréal: Presses de l'Université de Montreál, 1989.

Rohlfs, Gerhard. Grammatica storica della lingua italiana e dei suoi dialetti. 2. Morfologia. Torino: Einaudi, 1966.

Rossini, Giorgio. Capitoli di morfologia e sintassi del dialetto cremonese. Firenze: La Nuova ltalia Editnce, 1975.

Savi, Joseph. Éléments de dialectolgie italienne. Paris: Centre de recherches de langue et littérature italiennes, 1981.

Tonetti, Federico. Dizionario del dialetto valsesiano, preceduto da un saggio di grammatica. Bologna: Fomi, 1967.

Wang, William S.-Y. "Competing Changes as a Cause of Residue." Language 45:1 (1969): 9-25. Wexler, Kenneth, and Maria R. Manzini. "Parameters and Learnability in Binding Theory". Thomas Roeper and Edwin Williams, eds. Parameter Setting. Dordrecht: Reidel, 1987. 41-76. Zamboni, Alberto. Veneto. Pisa: Pacini, 1974. 